\title{
ИСТОРИЗМ
}

\author{
Н.А. Балаклеец
}

\section{ОНТОЛОГИЧЕСКИЕ АСПЕКТЫ МОНАРХИЧЕСКОЙ ВЛАСТИ (на материале романа И.И. Лажечникова «Ледяной дом»)}

\begin{abstract}
Аннотация. Предметом исследования настоящей статьи являются онтологические характеристики монархической власти, представленные в историческом романе И.И. Лажечникова "Ледяной дом». В статье предложена авторская интерпретация идей и образов Лажечникова в контексте современных политикофилософских учений. Привлекая для анализа теоретические разработки А. Кожева, Ж. Батая, Ж. Бодрийяра, М. Фуко, Э. Канторовича, М. Ямпольского и других исследователей, автор выявляет разнообразные формы и способы осуществления власти, представленные в романе. Особое внимание уделяется феноменам тела монарха, дискурса власти и способам трансгрессии власти.
\end{abstract}

Наряду с общенаучными методами исследования автор использует герменевтическую и постструктуралистскую методологию, а также элементы сравнительного литературоведения.

Основным результатом проведённого исследования является экспликация автором четырёх уровней бытия власти, представленных в романе "Ледяной дом». Кризис метафизического начала власти, выраженный в неспособности императрицы Анны Иоанновны осуществлять репрезентацию трансценденции, усугубляется кризисом репрезентации коллективного тела в публичном пространстве. Особым вкладом автора в проведённое исследование является выявление специфических характеристик дискурса власти, а также интерпретация смехового начала культуры как одного из элементов дискурса власти.

Ключевые слова: власть, дискурс, онтология, трансценденция, трансгрессия, тело, шутовство, пространство, Лажечников, "Ледяной дом».

Abstract. The aim of this article is to explicate the ontological characteristics of the monarch's power represented in the historical novel of Ivan Lazhechnikov "The House of Ice". In the article the author offers the interpretation of Lazhechnikov's ideas and images in terms of contemporary political and philosophical doctrines. Involving the theoretical studies of Alexandre Kojève, Georges Bataille, Jean Baudrillard, Michel Foucault, Ernst Kantorowicz, Mikhail lampolski and other researchers into the analysis, the author reveals a variety of forms and ways of power represented in the novel. Particular attention is paid to the phenomena of monarch's body, discourse of power and ways of power transgression. Along with the general scientific methods of research the author uses the hermeneutic and poststructuralist methodology as well as elements of comparative literary studies. The most important result of the research is the explication by the author of four levels of power being represented in the novel "The House of Ice ". The crisis of the metaphysical foundation of the power expressed in the inability of Empress Anna Ivanovna to represent the transcendence is compounded by the crisis of representation of the collective body in public space. The special contribution of the author consists in explanation of the specific characteristics of the discourse of power as well as the interpretation of laughter as one of the elements of the discourse of power.

Keywords: Lazhechnikov, power, discourse, ontology, transcendence, transgression, body, jester, space, "The House of Ice".

$\Pi$

роблема власти - одна из центральных в классическом философском дискурсе начиная с античных мыслителей [1; 2] и заканчивая Г.В.Ф. Гегелем [3]. В современной неклассической философии разрабатывается большое количество онтологических концепций власти [4-10 и др.]. В фокусе внимания исследователей оказываются не только формы властеосуществления, характерные для Нового и Новейшего времени, но и архаические формы господства, 


\section{Историзм}

пространственные и временные аспекты монархической власти, специфика политического тела короля. Господство монарха рассматривается как особый способ бытия власти [7; 9]. На наш взгляд, неослабевающий интерес современных исследователей к историческим формам бытия власти обусловлен не только стремлением более выпукло представить на их фоне современные способы господства и подчинения, но и установкой на постижение причин их кризиса.

Эвристический потенциал современных философских теорий власти может быть раскрыт путем применения их концептов к сфере анализа произведений художественной литературы. Цель настоящей статьи - эксплицировать онтологические характеристики власти, представленные в историческом романе И.И. Лажечникова «Ледяной дом» [11], т.е. раскрыть те её свойства, которые принадлежат её сущности, составляют способ её бытия.

Исторический роман представляет собой открытую систему смыслов: одни смыслы, прецедентные феномены (исторические и культурные аллюзии, коннотации) постепенно стираются из коллективной памяти, однако на смену им постоянно рождаются новые. С течением времени текст обрастает многообразием новых красок и возможностей интерпретации. Известное герменевтическое правило Ф. Шлейермахера, требующее понимания автора «лучше, чем он сам понимает себя, ибо он не осознаёт многого из того, что осознается нами» [12, c. 77] применительно к анализу исторического романа может быть осмыслено следующим образом: читатель и интерпретатор подобного рода текста должен руководствоваться не столько принципами исторической истинности, объективности и фактологической точности описываемых автором событий, сколько его литературно-художественными особенностями, идейным и смысловым своеобразием, эмоционально-образным содержанием, а такжеесли речь идёт о философской интерпретации - интенцией обнаружения имплицитно присутствующих в тексте онтологических оснований.

Любое художественно-историческое произведение содержит не только отпечаток духа своей эпохи, Zeitgeist, но и определённое свойственное ей понимание отношений власти, ибо исторический дискурс не существует в отрыве от политического. И одна из задач автора исторического романа заключается в расстановке исторических акцентов, оценке описываемых событий через призму многоуровневых и многообразных культурных наслое- ний. В этом плане роман И.И. Лажечникова «Ледяной дом», увидевший свет в 1835 г., представляет ценность не только в эстетико-художественном, историческом и социокультурном аспектах, но и даёт богатый материал для исследования описываемых в нём отношений власти, её типологии, способов её трансгрессии (преодоления).

Власть в романе осуществляется посредством поступков и действий конкретных живых людей. Современному читателю данная идея представляется очевидной, однако позволим себе напомнить, с каким трудом она пробивала себе дорогу в европейской теоретической мысли, на протяжении многих столетий зависимой от идеи метафизической предопределённости исторических событий. В этом смысле история идей представляет собой самостоятельный процесс, протекающий гораздо медленнее по сравнению с человеческой историей. Лишь в XVIII столетии в работе Дж. Вико «Основания новой науки об общей природе наций» был отчетливо артикулирован тезис: «Мир Наций был, безусловно, сделан Людьми <...> (выделено мной H.Б.), и потому способ его возникновения нужно найти в модификациях нашего собственного Человеческого Сознания» [13, с. 118]. Люди, творящие историю в романе «Ледяной дом», - это не широкие народные массы, а «несколько пылких самоотверженных голов», избранные представители политической элиты общества: «Тогдашний народ, включая и дворянство, погрязший в невежестве и раболепном страхе, кряхтел, страдал, но так же охотно бегал смотреть на казнь своих защитников, как бы на казнь утеснителей своих» [11, с. 127].

На наш взгляд, всё многообразие способов и форм бытия власти, представленных в «Ледяном доме», можно подразделить на следующие уровни:

1. Высший метафизический уровень власти его воплощением призвана служить императрица Анна Иоанновна. В соответствии с типологией власти, предложенной А. Кожевым [4], способ господства императрицы над своими подданными соответствует власти Отца: это наследственный тип власти, незыблемость и естественный характер которого оправдываются его метафизическим, божественным происхождением. Метафизический характер императорской власти возвышает её над конкретно-историческим социальным порядком, над её подданными и даже над её носителем и проводником - монархом, действующим не как частное лицо, но как выразитель надындивидуального начала. Неслучайно даже самый рев- 


\section{Филология: научные исследования 2(18) • 2015}

ностный противник Бирона Волынский не смеет посягать на трансцендентность высшей власти «матушки государыни» и стремится завоевать её «милость» $[11$, с. 134]. Однако Лажечников неоднократно подчеркивает политическую несостоятельность Анны, её неспособность служить проводником и выразителем метафизического начала власти, нести тяжкое бремя господства не только над социально-политическим целым, но и над собой. Императрица изображается в романе как слабая больная женщина, подверженная капризам и не способная самостоятельно принимать судьбоносные политические решения. «Старая, хворая, брюзгливая женщина всегда с причудами» [11, c. 141] - подобная нелестная самохарактеристика императрицы неоднократно повторяется и усиливается самим автором повествования: «Анна Иоанновна была больная женщина, и любимец её умел пользоваться её немощами» [11, с. 219], «Несчастия России, если и вполовину существовали, как ей изобразили, налегли на грудь ее, и без того растерзанную болезнями (выделено мной Н.Б.) и привычкою к предмету недостойному» [11, c. 239]. Однако монарх обладает не только бренным и преходящим физическим телом (что приравнивает его к простому смертному), но и телом политическим, бессмертным, обеспечивающим его связь с непреходящей божественной властью. И подчас «человеческое, слишком человеческое» не позволяет высшему суверену соответствовать своему политическому телу, и тогда перед нами разворачивается трагедия «двух тел» монарха (что показывает Е. Канторович на примере анализа образа английского короля в трагедии Шекспира «Ричард II») [14]. Очевидно, что, подобно шекспировскому Ричарду, нерешительная и болезненная императрица Анна, носящая «все признаки смерти» $[11$, с. 240], не способна в должной мере воплощать символическое тело власти. И этот диссонанс физической плоти и политического тела монарха не мог не отразиться на символическом теле государства, возглавляемого Анной. «При смерти» не только императрица, но и вся Россия, страдающая под гнётом временщиков. Отталкивающая внешность императрицы («смуглой, с длинным носом, тучной, мрачной» $[11$, с. 262]) выступает символом уродства установившейся в государстве системы власти. Лажечников описывает различные формы аномийных, извращенных социальных отношений, характерных для России времен царствования Анны Иоанновны, России, охваченной ужасом: это и изощренные пытки («Батоги, плети, окачивание на морозе водою, соленая пища без питья, тысячи жестокостей, какие только адская изобретательность умеет разнообразить и оттенить, употребляемы без всякого уважения к истинному несчастию и без всякой ответственности» [11, с. 241]); и вынужденное убийство собственных детей отцами - обнищавшими крестьянами, оказавшимися не в состоянии заплатить налоги в государственную казну [11, c. 242-243]; и разгул тайной канцелярии, и мода на допросы, и мода знати на «восточных уродцев», которых, подобно домашним питомцам, лелеяли, зачастую пренебрегая родными детьми.

Вместе с тем, описываемые в «Ледяном доме» уродливые формы осуществления власти не ставятся самим автором в вину императрице: она, будучи выразительницей высшего, трансцендентного закона, находится вне критики, над схваткой, которая размежевала придворную элиту. Такая позиция власти может быть прекрасно проиллюстрирована словами С.С. Аверинцева: для русского сознания «сама по себе власть ... - это нечто, находящееся вне человеческого мира, либо ниже его, но, во всяком случае, в него как бы и не входящее» [15, c. 235]. Кризис суверенной власти Анны Иоанновны связан с её онтологической неполнотой, неспособностью воплощать на практике принципы высшего Закона и справедливости. Ответственность за безвластие и беззаконие автор романа возлагает на фаворита императрицы курляндского герцога Эрнста Бирона.

Анна Иоанновна - не только выразительница монаршей воли, но и, прежде всего, женщина (что она сама подчеркивает), и гендерный аспект императорской власти играет в романе не последнюю роль. «Великая беда русской души <...> - в женственной пассивности, переходящей в «бабье», в недостатке мужественности, в склонности к браку с чужим и чуждым мужем», - отмечает Н.А. Бердяев [16]. Данный тезис не следует подвергать вульгаризованной интерпретации (в том смысле, что выразителем высшего начала власти в России непременно должен быть мужчина). Речь идёт о признании необходимости воплощения в фигуре монарха принципа маскулинности, способности активного созидательного оформления аморфной, расплывчатой культурной среды. Бирон и выступает по отношению к России, выражаясь словами Бердяева, таким «чуждым мужем», призванным привнести в систему власти внешнее, организующее, 


\section{Историзм}

упорядочивающее начало, но не справляющимся с данной задачей (да и в принципе отказывающимся эту задачу видеть).

Обобщая сказанное, следует отметить, что в образе императрицы воплощена идея кризиса метафизического начала власти. Нарушается сакральное и символическое измерение власти, состоящее в том, что имманентное, земное (монарх) репрезентирует трансцендентное, божественное. Применительно к образу Анны Иоанновны, представленному в романе Лажечникова, можно сделать вывод, что речь уже идёт не о репрезентации, но об искажении и извращении трансцендентного. Это вторая фаза развития образа в направлении от репрезентации к симуляции, согласно Ж. Бодрийяру. Вначале образ «отражает фундаментальную реальность» [17] - это метафизический порядок репрезентации, идея монарха как наместника и помазанника божьего. Затем «он маскирует и искажает фундаментальную реальность» [17]. Этой фазе соответствует ситуация, описываемая И.И. Лажечниковым в «Ледяном доме». Можно привести ряд аналогичных литературных примеров данной стадии кризиса и вырождения метафизически-репрезентативного порядка власти. Это, например, «Князь Серебряный» А.К. Толстого, где императрице соответствует образ Ивана Грозного. Характерно, что у царя разгул жестокости и самоуправства сочетается с «игрой» в монастырь, когда безбожные злодеи-опричники переодеваются монахами. Эта гротескная симуляция связи с высшим божественным порядком является свидетельством того, что подлинная соотнесенность власти с трансценденцией уже безвозвратно утрачена. Богослужение превращается в фарс. Другой пример даёт «Борис Годунов» А.С. Пушкина. Преступление Годунова против законного наследника престола представляет собой одновременно и люциферовский акт отрицания божественного порядка и метафизической иерархии власти. Тем самым Годунов уже не может исполнять взятую на себя роль проводника божественной власти. Поэтому его теснит и фактически свергает с престола ещё более откровенный богоборец и «антихрист»: бежавший из монастыря Григорий Отрепьев не искажает, но «маскирует отсутствие фундаментальной реальности» [17]. Не только он сам, но и помогающие ему поляки, и московские бояре, в сущности, знают, что он не настоящий царевич, но не придают этому обстоятельству какого-либо существенного значения: («Но знай, / Что ни ко- роль, ни папа, ни вельможи / Не думают о правде слов моих. / Димитрий я иль нет - что им за дело? / Но я предлог раздоров и войны» [18, с. 264]). Это уже третья фаза перехода образа в симулятивный порядок. В качестве следующей, завершающей стадии может быть рассмотрена ситуация, когда власть «вообще не имеет отношения к какой бы то ни было реальности, являясь своим собственным симулякром в чистом виде» [17]. В литературе данная фаза получит свое описание лишь во второй половине XX столетия. Так, в произведениях В. Сорокина «День опричника» и «Сахарный Кремль» Государь уже и не скрывает отсутствие фундаментальной реальности (трансценденции), но целиком является своим собственным симулякром. Таков результат гибели метафизического измерения власти. В романе Лажечникова показана начальная фаза этого процесса.

2. Второй уровень власти представлен борьбой за господство, которую ведет кабинет-министр Артемий Петрович Волынский, поддерживаемый немногочисленными единомышленниками, против Бирона и его сторонников. Власть Бирона ориентирована исключительно на имманентное, земное, конечное, временное (отсюда закрепленное за ним обозначение «временщик»), тогда как Волынский - тот, кто пытается восстановить трансценденцию в её живом и исконном смысле, преодолеть метафизический кризис власти, все более усугубляющийся разрыв между трансцендентным и имманентным.

Между Бироном и Волынским разыгрывается борьба не на жизнь, а на смерть, связанная с риском и желанием добиться признания, и именно это обстоятельство позволяет нам охарактеризовать противоборство между двумя этими соперниками как попытку установления власти Господина (в соответствии с классификацией А. Кожева [4]). Внешняя цель этой борьбы заключается в том, чтобы склонить императрицу на свою сторону, ибо каждый из оппонентов прекрасно понимает: добиться своих политических целей, спасти (или погубить) Россию можно лишь через государыню. Таким образом, приближенность подданного к императрице в физическом пространстве соответствует его повышению в символической иерархии отношений власти, и наоборот. Властная символика и атрибутика может транслироваться определёнными позициями и диспозициями человеческих тел. Взаимное расположение тел в системе установленных пространственных конфигураций 


\section{Филология: научные исследования 2(18) • 2015}

и оппозиций (например, обязанность подданных стоять в присутствии сидящего монарха; нищий, сидящий на корточках перед проходящими мимо людьми) может рассматриваться как элемент, манифестирующий логику властных отношений: «Нет более примитивной формы власти, чем та, которую осуществляет само тело» [19, с. 475]. Показательны в этом плане сцены романа, в ходе которых императрица выбирает себе провожатого и подаёт ему руку: её благосклонность падает поочередно то на Бирона, то на Волынского.

Однако за борьбой герцога курляндского и кабинет-министра стоят разные мотивы осуществления власти: если власть временщика основана на подкупе и запугивании союзников («Липман, готовый на все низости и злодейства, служил своему покровителю и единомышленнику из честей и злата» $[11$, с. 118]), то Волынский прилагает все усилия, чтобы руководствоваться в своих действиях соображениями не индивидуальной выгоды, но общего блага. Глубинный мотив, скрывающийся за действиями кабинет-министра и его союзников, заключается в восстановлении попранного временщиком Закона: «Не нарушали мы закона, но шли против беззакония в лище временщика» [11, c. 279], - восклицает один из сторонников Волынского Эйхлер.

На протяжении романа оба - и Волынский и Бирон - неоднократно демонстрируют свою готовность умереть в борьбе с противником. «Я или он должен погибнуть!», - восклицает разгневанный временщик после разговора с кабинет-министром [11, с. 137]. В одной из заключительных сцен романа Бирон настаивает на том, чтобы колеблющаяся императрица подписала смертный приговор «мятежникам» во главе с Волынским, в противном случае он готов пожертвовать своей жизнью: «Моя или его голова должна слететь; нет середины, ваше величество! Избирайте» [11, c. 297]. Волынский и его ближайшие соратники Щурхов и Перокин (данные фамилии являются анаграммами реальных исторических деятелей Хрущова и Еропкина) мужественно принимают смерть. Но эта смерть - не просто выражение политической мести, это жертва, предваряющая скорый закат бироновщины и наступление нового социально-политического порядка, основанного на реставрации поруганного Закона.

Образ Бирона, представленный на страницах «Ледяного дома», послужил основой для создания аллюзий в произведениях русской литерату- ры. К примеру, одно из сравнений из «Былого и дум» А.И. Герцена («как Бирон, вылил мне в декабре месяце ушат холодной воды на голову» [20, c. 278]) отсылает к знаменитой сцене пыток людьми Бирона малоросса Горденко, когда тот, облитый на морозе ушатами холодной воды, был буквально превращен в ледяную статую. Роман П.В. Полежаева «Бирон и Волынский» воспроизводит многие сцены «Ледяного дома»: это и знаменитая сцена шутовской свадьбы, и «родины козы», и сцена подписания смертного приговора Волынскому [21].

Отдельного упоминания заслуживают макиавеллевские мотивы в произведении Лажечникова. Фамилия Макиавелли неоднократно упоминается на страницах «Ледяного дома», причём как в связи с фигурой Волынского, так и в сравнении с Бироном. Секретарь кабинет-министра Зуда неоднократно напоминает ему о необходимости следовать макиавеллевским принципам: «Осмотритесь! вы забыли уроки Махиавеля...» [11, с. 14]; «не угодно ли будет запастись орудиями Махиавеля; они вам очень нужны» [11, с. 54]. Однако в силу своего характера пылкий и неосмотрительный Волынский по собственному признанию не способен следовать провозглашаемым в «Государе» принципам «лукавства и осторожности». Зуда по велению кабинет-министра перевел макиавеллевского «Государя» для поднесения императрице. Текст трактата, безусловно, мог бы оказаться для неё полезным: признавая бесспорный приоритет власти наследственной, основанной на силе традиций, над властью недавно учрежденной, Макиавелли предлагает монаршим особам множество рекомендаций, направленных на укрепление государственной власти. Этой цели, согласно мысли итальянского автора, можно достичь следующими способами: руководствоваться в своих действиях не общественным мнением, но соображениями усиления собственного могущества с опорой на закон и силу, в случае необходимости («ради сохранения государства») допускается отступление от собственного слова. В то же время государю следует стараться не возбуждать против себя народного гнева: «Он должен побуждать граждан спокойно предаваться торговле, земледелию и ремеслам, чтобы одни благоустраивали свои владения, не боясь, что эти владения у них отнимут, другие - открывали торговлю, не опасаясь, что их разорят налогами; более того, он должен располагать наградами для тех, кто заботится об украшении города 


\section{Историзм}

или государства» [22, с. 72-73]. Таким образом, макиавеллизм как систему политических принципов не следует трактовать упрощенно, исключительно как синоним лицемерия и политического прагматизма. Как показывает Э. Кассирер, миф о Макиавелли получил своё распространение отнюдь не только благодаря политикам или философам, но и, прежде всего, литераторам: так, в английской литературе Елизаветинской эпохи насчитывается не менее 395 упоминаний фамилии итальянского автора. И Кристофер Марло, и Бенджамин Джонсон, и Уильям Шекспир трактовали макиавеллизм как синоним жестокости, лукавства, лицемерия и злодейства [23, с. 155]. (На наш взгляд, обвинение в культивировании разнообразных политических мифов можно предъявить литературному дискурсу в целом). Очевидно, что многочисленные литературные памятники исходят из довольно плоского понимания макиавеллизма, связывая его исключительно с психологическими особенностями субъекта политики. В этом смысле и Бирон у Лажечникова признан макиавеллистом: («зачем было добиваться чувства у этого сердиа, иссохшего на Махиавеле!..» [11, с. 281]). Однако подлинный макиавеллизм глубже: он выражается не только в требовании рассматривать личные интересы превыше государственных, но и в обособлении сферы политики в качестве автономной области функционирования власти, не зависимой от религии, этики, метафизики, в изоляции государства в «пустом пространстве» $[23$, с. 184$]$

3. Следующий уровень власти образован действующими в романе представителями народных масс. Как уже отмечалось нами выше, народ в «Ледяном доме» не обладает самосознанием и не может претендовать на статус полноценного политического субъекта. Если автор и вводит в свое повествование персонажей «из народа» (слуги, горничные, крестьяне, торговцы около Гостиного двора, цыгане), то практически всегда эти персонажи отсылают к фигурам более значительным, выполняют посредническую функцию (доносительство, шпионаж). Лажечников, смешивая частное и публичное измерения политики, показывает, что власть вершится не только во дворцах и королевских покоях, но и частное пространство не может быть полностью свободным от присутствия политических акторов. Публичное пространство, представленное в романе, характеризуется утратой своей функции собирания полиголосного и полиперспективного.
Улицы и площади зимнего Петербурга, в котором развертывается действие романа, отличаются пустотой и безмолвием. Огромное, безмолвное, мрачное пространство Петербурга времен Бирона не является пространством очеловеченным, оно, несмотря на гигантские, подавляющие его жителей размеры, не способно служить для них приютом и пристанищем. Пространство города более не вмещает человека, оно противостоит ему как внешняя, чуждая, негостеприимная среда, принадлежащая временщику и его слугам. Для усиления эффекта оторванности пространства от его обитателей Лажечников прибегает к контрастному описанию многолюдного, многоголосного пространства Летнего дворца и Летнего сада времён царствования Петра I и опустевшего сада во времена бироновщины. Если в славные времена Петра «сад бывал сборным местом всего Петербурга, <..> Все говорили вслух о том, что было у них на душе, потому что в душе ничего не таилось против хозяина. Аллеи кипели и шумели <...> Только темная ночь разгоняла пирующих», то теперь «Ужас царствует вокруг этого жилища; сад и в праздниках и в будни молчалив; не нужно отгонять от него палкою, - и без неё его убегают, как лабиринта, куда попавшись, попадешься к Минотавру на съедение» [11, с. 29-30]. Многоголосье сменилось безмолвием - право на лапидарный дискурс в публичном пространстве отныне принадлежит особому субъекту - Языку (уголовному преступнику, указывающему властям на своих соучастников): провозглашаемый им пароль «слово и дело» служит перформативом, влекущим за собой немедленный арест любого лица, на которое укажет Язык. Таким образом, народ лишился некогда доступного ему права на дискурс в публичном пространстве, да и само пребывание в этом пространстве сделалось исключительно вынужденным и подчиненным строго функциональным целям: «Пусто было на улищах и площадях; лишь изредка мелькал курьер, сидя на облучке закрытой кибитки; по временам шныряли подозрительные лица или гремели мерным звуком цепи и раздавалась заунывная песнь колодников...» [11, с. 25].

Дискурс власти, представленный в романе, является асимметричным: власть задаёт вопросы, допрашивает, но не позволяет вопрошать и даже высказываться о носителях власти: «Он такой $ф а-$ ворит, что нельзя о нем и говорить» [11, с. 51]. В приёмных покоях Бирона «слов между приходящими не слышно» [11, с. 115], а сам он, давая рекомендации молодому секретарю Эйхлеру, признает, что 


\section{Филология: научные исследования 2(18) • 2015}

«первый враг - язык» [11, с. 120]. Народ здесь, как и у Пушкина, безмолвствует.

У власти и подвластных нет общего языка: если дискурс власти должен повлечь за собой «реальные», физические последствия, то функция подвластных заключается в одностороннем выслушивании и исполнении приказов. Подвластный лишён права быть услышанным, его голос - это голос самой власти. Вопросно-ответный дискурс власти по сути своей является монологическим, автореферентным: необходимость ответа и его границы уже включены в ситуацию вопрошания, в область предзнания власти об индивидах. Вопрошая, учиняя допросы в Тайной канцелярии, власть заранее знает ответы на них и ожидает лишь подтверждения своей легитимности.

Способ бытия власти в обществе в любую эпоху предполагает наличие особых форм реализации её в пространстве, а также конституирования ею особых пространств. Апофеозом власти в романе Лажечникова является создание ею уникального безжизненного пространства - ледяного дома. Предназначенный для проведения шутовской свадьбы, ледяной дворец приобретает множество символических значений и коннотаций: это и место последнего свидания Волынского и его возлюбленной Мариорицы, за которым последует смерть обоих героев; это и памятник замученному людьми Бирона малороссийскому дворянину Горденко; это и образ всей России, застывшей в ужасе под властью временщика. Ледяной дом символизирует небывалую роскошь и внешнее великолепие власти («он казался высеченным из одного куска сапфира, убранного фигурами из опала» [11, c. 164]) и одновременно её хрупкость и шаткость («Ледяной дом рухнулся; уцелевшие льдины развезены по погребам» [11, с. 303]).

4. Смешение перечисленных выше уровней власти достигается путём её трансгрессии [24; 25]. Высокое и низкое, трагическое и комическое, благородное и низменное смешиваются вплоть до неразличимости: «кабинет-министр занимался шутовским праздником с таким же вниманием и страхом, как бы дело шло об устройстве государства» [11, с. 13]; «Князья, люди первых фамилий русских <...> спешат наперерыв записаться в скоморохи, в шуты...» [11, с. 53]; «Скоморохи предпочтены истинным слугам отечества» [11, с. 221].

Анна Иоанновна как реальная историческая фигура боролась с традиционным для русской средневековой культуры феноменом юродства [26, с. 182] и окружила себя многочисленными придворными шутами. Изгнав юродивых из сферы политики, монархическая власть разрушила традиционный средневековый институт протеста [26, с. 180]. Шутовство в эпоху Нового времени, в отличие от юродства и средневекового шутовства, уже не выполняет антидискурсивную, трансгрессивную функцию по отношению к дискурсу власти, связанную с выражением народной, «неофициальной правды» (А.Н. Веселовский); в эту эпоху происходит «огосударствление праздничной жизни» (М.М. Бахтин) [27, с. 41]. Институт шутовства, представленный в романе Лажечникова, ассимилирован системой властных отношений. Смех шутов при дворе Анны Иоанновны органично вписывается в официальный дискурс власти. Весьма показательной является одна из глав «Ледяного дома» под названием «Родины козы», повествующая о шутливом поклонении императрицы и самых знатных её подданных козе одного из придворных шутов: «Введенная в спальню родильницы, государыня подошла $к$ постели, изволила высыпать из кошелька на особо приготовленную подушку несколько десятков золотых монет на зубок и потом спросила госпожу Педрилло об её здоровье. Родильница (тиснутая за ногу повивальною бабкой) преумилительно заблеяла ответ, и вместе с этим весь её козий штат заблеял хором: кто басом, кто тенором, кто дискантом, чему её величество изволила от души смеяться <... потом, когда Анна Иоанновна присела на кресла, герцог вызывал по этому списку всех посетителей и посетительниц, одного за одним, по классам, с тем чтобы они подходили к родильнице и исполняли то же, что сделала государыня <...> На сцене одни шуты удерживали своё хладнокровие и важность, от чего ещё более усиливалось смешное зрелище. Одним словом, потеха была такая, что государыня забыла свою болезнь и хохотала до слёз; всё за нею смеялось также, не в состоянии быв соблюсти должного приличия, чем она нимало не оскорблялась» [11, с. 218]. Но этот смех лишён «возрождающего и творческого начала» (М.М. Бахтин). Это смех, покинувший широкие просторы площадей и неофициальных карнавальных пространств и заключенный в тесные рамки придворного пространства. Лажечников, вопреки выводам Бахтина о том, что власть и насилие несовместимы со смеховым дискурсом [27, c. 104], демонстрирует органичность присутствия смехового начала в дискурсе власти. Смех шутов, 
окруживших власть, способствует ещё большему нивелированию её трансцендентной сущности и погружению её в имманентное.

На наш взгляд, уместно провести параллель между рассмотренным выше эпизодом из «Ледяного дома» и праздником осла из четвертой части «Так говорил Заратустра» Ф. Ницше: «И действительно! все эти высшие люди, два короля, папа в отставке, злой чародей, добровольный нищий, странник и тень, старый прорицатель, совестливый духом и самый безобразный человек, все они, как дети или старые бабы, стояли на коленях и молились ослу» [28, с. 314]. К.А. Свасьян в своих комментариях отмечает, что Ницше здесь «следовал давнишней маргинальной традиции церковной истории, известной как festum asinorum. Праздник осла, относящийся к литургии приблизительно так же, как драма сатиров к трагедии, составлял значительную часть общей смеховой культуры Средневековья. Данные о нем восходят ещё к V в.; с 633 г. начинаются запреты, ужесточавшиеся в XII-XIII вв.; впрочем, сама Сорбонна защищала эту традицию вплоть до её окончательного осуждения в 1544 г.» [29, с. 790]. И у Лажечникова, и у Ницше описывается трансгрессивное смешение высокого божественного и низменного земного, животного. Но применительно к «Заратустре» Ницше такое смешение не следует воспринимать в качестве банального кощунства и святотатства. Смысл здесь более глубокий. Божественное не отрицается, но переводится в самые низменные пласты земного, достигает максимальной степени самоотчуждения. Бог воплотился в Человека, и был подвергнут унижениям, истязаниям и позорной смерти. И тем самым он проявил свое наивысшее могущество. Не будет ли ещё большим проявление могущества переход божественного в животное, причем в одно из наиболее презираемых? А почитание бога в этом унизительном образе - не будет ли высшим проявлением благочестия? Так или иначе, в этом трансгрессивном действе снимается резкая противопоставленность божественного и земного, устраняется катастрофический разрыв между трансцендентным и имманентным: «Лучше молиться Богу в этом образе, чем без всякого образа. Поразмысли об этом изречении, мой высокий друг - и ты скоро убедишься, что в этом изречении скрывается мудрость» [28, с. 316]. Трансгрессия выступает на передний план тогда, когда власть трансценденции перестает функциониро- вать должным образом, когда «Бог умер» - т.е., когда трансцендентное настолько возвысилось, что перестало соотноситься с имманентным, перестало проявлять себя в нем. Трансгрессия подчас в грубой форме - возвращает утраченную трансценденцию в область имманентного, божественное (пусть и гротескным образом) приобщается земному. Таким образом, если у Ницше праздник осла представляет собой попытку воскресить умершего Бога, то у Лажечникова родины козы - это скорее стремление придать смерти ещё не совсем исчезнувшего из пространства власти Бога: «убить Бога, чтобы освободить жизнь от его существования, которое её ограничивает» [30]. Смех убивает, и смех - одна из возможных причин смерти Бога у Ницше (в «Так говорил Заратустра» предлагается версия, что боги засмеяли себя до смерти, услышав положение, что есть только один Бог [28, с. 187]).

Подводя итоги настоящего исследования, отметим, что роман И.И. Лажечникова «Ледяной дом» демонстрирует разнообразие форм и способов осуществления власти. В произведении можно эксплицировать, по меньшей мере, четыре уровня власти. Первый уровень выражает кризис метафизического начала власти: трансценденция, которая должна представлять собой сверхчувственную основу монархической власти, утрачивает свою силу. Второй уровень власти представлен борьбой, с одной стороны, за восстановление её метафизического основания, с другой стороны, за утверждение власти чистой имманентности, посюсторонности, лишенной высшего основания. Третий уровень функционирования власти связан с кризисом репрезентации коллективного тела в публичном пространстве и все большим обособлением от него дискурса власти. Наконец, четвертый уровень власти предполагает её трансгрессию - нивелирование трансцендентного и имманентного, высокого и низкого, земного и небесного путем актуализации смехового элемента дискурса власти. Таким образом, в романе представлена как классическая, так и современная онтология власти. Если классическая онтология репрезентирована монархической властью (которая показана лишь в негативном аспекте - позитивно она дана только в стадии кризиса и разложения), то неклассическая онтология связана с трансгрессивными феноменами, предполагающие совершенно иные, отличные от классических, способы бытия власти. 


\section{Филология: научные исследования 2(18) • 2015}

\section{Список литературы:}

1. Платон. Государство. СПб.: Наука, 2005. 569 с.

2. Аристотель. Политика. М.: АСТ, 2002.400 с.

3. Гегель Г.В.Ф. Философия права. М.: Мысль, 1990. 524 с.

4. Кожев А. Понятие власти. М.: Праксис, 2006. 192 с.

5. Бодрийяр Ж. Символический обмен и смерть. М.: Добросвет, 2000. 387 с.

6. Фуко М. Надзирать и наказывать. М.: Ad Marginem, 1999. 479 с.

7. Фуко М. Психиатрическая власть. СПб.: Наука, 2007. 450 с.

8. Ямпольский М. Физиология символического. Книга 1. Возвращение Левиафана: Политическая теология, репрезентация власти и конец Старого режима. М.: Новое литературное обозрение, 2004. 800 с.

9. Исаев И.А. Господство: Очерки политической философии. М.: Норма, 2008. 352 с.

10. Исаев И.А. Топос и номос: пространства правопорядков. М.: Норма, 2007. 416 с.

11. Лажечников И.И. Сочинения в двух томах. Т. 2. М.: Гослитиздат, 1963.732 с.

12. Шлейермахер Ф. Герменевтика. СПб.: Европейский Дом, 2004. 242 с.

13. Вико Дж. Основания Новой науки / Пер. с итал. М.; К.: REFL-book - ИСA, 1994. 656 c.

14. Канторович Э. Два тела короля. Исследование по средневековой политической теологии. М.: Изд-во Института Гайдара, 2014. 744 с.

15. Аверинцев С.С. Византия и Русь: два типа духовности // Новый мир. 1988. № 9. С. 227-239.

16. Бердяев H.A. O «вечно бабьем» в русской душе. (URL: http://www.vehi.net/berdyaev/rozanov.html (дата обращения: 01.06.2015)).

17. Бодрийяр Ж. Симулякры и симуляция. (URL: http://lit.lib.ru/k/kachalow_a/simulacres_et_simulation.shtml (дата обращения: 01.06.2015)).

18. Пушкин А.С. Борис Годунов // Пушкин А.С. Собр. соч. в 10 т. Т. 4. М.: ГИХЛ, 1960. С. 201-298.

19. Канетти Э. Масса и власть. М.: Астрель, 2012. 574 с.

20. Герцен А.И. Былое и думы. Части 6-8. М.: ГИХЛ, 1958. 640 с.

21. Полежаев П.В. Бирон и Волынский. Харьков: Рубикон, 1994. 480 с.

22. Макиавелли Н. Государь. М.: Эксмо, 2013. 544 с.

23. Cassirer E. Vom Mythos des Staates. Hamburg: Meiner, 2002.

24. Батай Ж. «Проклятая часть»: Сакральная социология. М.: Ладомир, 2006. 742 с.

25. Фаритов В.Т. Субъект и сознание в режиме трансгрессии // Философия и культура. 2015. № 4. С. $496-504$. (DOI: 10.7256/1999-2793.2015.4.10907).

26. Лихачев Д.С., Панченко А.М. «Смеховой мир» Древней Руси. Л.: Наука, 1976. 204 с.

27. Бахтин М.М. Творчество Франсуа Рабле и народная культура средневековья и Ренессанса. М.: Художественная литература, 1990. 543 с.

28. Ницше Ф. Полн. собр. соч. в 13 т. Т. 4: Так говорил Заратустра. Книга для всех и ни для кого. М.: Культурная революция, 2007. 432 с.

29. Ницше Ф. Соч. в 2 т. Т. 2. М.: РИПОЛ КЛАССИК, 1998. 864 с.

30. Подорога В. Событие: Бог мёртв. Фуко и Ницше. (URL: http://www.nietzsche.ru/look/xxc/ontologie/vpodoroga/ (дата обращения: 01.06.2015)).

31. Фаритов В.Т. Трансценденция как онтологический горизонт научного дискурса (философия науки М. Хайдеггера) // Философская мысль. 2014. № 11. C. 1-31. (DOI: 10.7256/2409-8728.2014.11.14186. URL: http://www.e-notabene. $\mathrm{ru} / \mathrm{fr} /$ article_14186.html).

32. Фаритов В.Т. Дискурс и трансгрессия. Перспективы онтологического исследования // Философская мысль. 2015. № 3. C. 1-9. (DOI: 10.7256/2409-8728.2015.3.14919. URL: http://www.e-notabene.ru/fr/article_14919.html).

\section{References (transliteration):}

1. Platon. Gosudarstvo. SPb.: Nauka, 2005.569 s.

2. Aristotel'. Politika. M.: AST, 2002. $400 \mathrm{~s}$.

3. Gegel' G.V.F. Filosofiya prava. M.: Mysl', 1990. 524 s.

4. Kozhev A. Ponyatie vlasti. M.: Praksis, 2006. 192 s.

5. Bodriiyar Zh. Simvolicheskii obmen i smert'. M.: Dobrosvet, 2000. 387 s.

6. Fuko M. Nadzirat' i nakazyvat'. M.: Ad Marginem, 1999. $479 \mathrm{s.}$

7. Fuko M. Psikhiatricheskaya vlast'. SPb.: Nauka, 2007. $450 \mathrm{~s}$.

8. Yampol'skii M. Fiziologiya simvolicheskogo. Kniga 1. Vozvrashchenie Leviafana: Politicheskaya teologiya, reprezentatsiya vlasti i konets Starogo rezhima. M.: Novoe literaturnoe obozrenie, 2004. $800 \mathrm{~s}$.

9. Isaev I.A. Gospodstvo: Ocherki politicheskoi filosofii. M.: Norma, 2008. $352 \mathrm{s.}$

10. Isaev I.A. Topos i nomos: prostranstva pravoporyadkov. M.: Norma, 2007. $416 \mathrm{~s}$.

11. Lazhechnikov I.I. Sochineniya v dvukh tomakh. T. 2. M.: Goslitizdat, 1963. 732 s.

12. Shleiermakher F. Germenevtika. SPb.: Evropeiskii Dom, 2004. 242 s. 
13. Viko Dzh. Osnovaniya Novoi nauki / Per. s ital. M.; K.: REFL-book - ISA, 1994. 656 s.

14. Kantorovich E. Dva tela korolya. Issledovanie po srednevekovoi politicheskoi teologii. M.: Izd-vo Instituta Gaidara, 2014. $744 \mathrm{~s}$.

15. Averintsev S.S. Vizantiya i Rus': dva tipa dukhovnosti // Novyi mir. 1988. № 9. S. 227-239.

16. Berdyaev N.A. O «vechno bab'em» v russkoi dushe. (URL: http://www.vehi.net/berdyaev/rozanov.html (data obrashcheniya: 01.06.2015)).

17. Bodriiyar Zh. Simulyakry i simulyatsiya. (URL: http://lit.lib.ru/k/kachalow_a/simulacres_et_simulation.shtml (data obrashcheniya: 01.06.2015)).

18. Pushkin A.S. Boris Godunov // Pushkin A.S. Sobr. soch. v 10 t. T. 4. M.: GIKhL, 1960. S. 201-298.

19. Kanetti E. Massa i vlast'. M.: Astrel', 2012.574 s.

20. Gertsen A.I. Byloe i dumy. Chasti 6-8. M.: GIKhL, 1958. 640 s.

21. Polezhaev P.V. Biron i Volynskii. Khar'kov: Rubikon, 1994. 480 s.

22. Makiavelli N. Gosudar'. M.: Eksmo, 2013. 544 s.

23. Cassirer E. Vom Mythos des Staates. Hamburg: Meiner, 2002.

24. Batai Zh. «Proklyataya chast'»: Sakral'naya sotsiologiya. M.: Ladomir, 2006. $742 \mathrm{~s}$.

25. Faritov V.T. Sub"ekt i soznanie v rezhime transgressii // Filosofiya i kul'tura. 2015. № 4. S. 496-504. (DOI: 10.7256/19992793.2015.4.10907).

26. Likhachev D.S., Panchenko A.M. «Smekhovoi mir» Drevnei Rusi. L.: Nauka, 1976. 204 s.

27. Bakhtin M.M. Tvorchestvo Fransua Rable i narodnaya kul'tura srednevekov'ya i Renessansa. M.: Khudozhestvennaya literatura, 1990. $543 \mathrm{~s}$.

28. Nitsshe F. Poln. sobr. soch. v 13 t. T. 4: Tak govoril Zaratustra. Kniga dlya vsekh i ni dlya kogo. M.: Kul'turnaya revolyutsiya, 2007. $432 \mathrm{~s}$.

29. Nitsshe F. Soch. v 2 t. T. 2. M.: RIPOL KLASSIK, 1998. 864 s.

30. Podoroga V. Sobytie: Bog mertv. Fuko i Nitsshe. (URL: http://www.nietzsche.ru/look/xxc/ontologie/vpodoroga/ (data obrashcheniya: 01.06.2015)).

31. Faritov V.T. Transtsendentsiya kak ontologicheskii gorizont nauchnogo diskursa (filosofiya nauki M. Khaideggera) // Filosofskaya mysl'. 2014. № 11. S. 1-31. (DOI: 10.7256/2409-8728.2014.11.14186. URL: http://www.e-notabene.ru/fr/ article_14186.html).

32. Faritov V.T. Diskurs i transgressiya. Perspektivy ontologicheskogo issledovaniya // Filosofskaya mysl'. 2015. № 3. S. 1-9. (DOI: 10.7256/2409-8728.2015.3.14919. URL: http://www.e-notabene.ru/fr/article_14919.html). 